\title{
Vertical and horizontal composition of fecal pollution indicator bacteria in lotic and lentic ecosystems at Turkish Thrace
}

\author{
PINAR ALTINOLUK-MIMIROGLU1* \\ BELGIN CAMUR-ELIPEK ${ }^{2}$ \\ ${ }^{1}$ Trakya University Technology Research \\ and Development Centre, 22030, Edirne, Turkey; \\ ${ }^{2}$ Trakya University Faculty of Science, \\ Department of Biology, 22030, Edirne, Turkey \\ *Correspondence: \\ e-mail: pinar_altinoluk@yahoo.com.tr
}

Key words: Fecal coliform, Escherichia coli, public health, freshwater resources, environmental relationships.
Received April 14, 2016.

Revised August 03, 2016.

Accepted August 04, 2016

\begin{abstract}
Background and Purpose: Although freshwater ecosystems have natural bacterial populations, their distributions are negatively affected by agricultural activities, domestic and industrial discharges. Bacterial composition at different depths can limit the usage of the water column for drinking, irrigation or other intentions. This study was designed to give similar indications concerning the nature of distribution of indicator bacteria in two different freshwater ecosystem types (lotic and lentic biotopes), and also to identify the factors that might be responsible in shaping them.
\end{abstract}

Materials and Methods: For this aim, stagnant and running water resources located in Meric-Ergene River Basin at Turkish Thrace were sampled at three water depths (surface, middle, bottom) and two sediment depths (shore and bottom) between the dates October 2014 and September 2015 at seasonal intervals. While the heterotrophic bacteria, total and fecal coliform bacteria, and Escherichia coli were recorded by the CFU and MPN techniques, some features (temperature, dissolved oxygen, $\mathrm{pH}$, conductivity, salinity, nutrients, ions, and elements) were also measured by classical chemical, chromatographic or spectrometric methods.

Results and Conslusions: According to the data, the bacterial distribution in each ecosystem was found as similar for the bottom and the surface water columns. Results were also supported statistically by Bray-Curtis similarity index and correspondence analyse. The relationships between the bacterial distribution and environmental features were evaluated by Spearman correlation index. Consequently, it was observed that the bacterial distribution can differ in both water column/sediment depths and loticl lentic ecosystems. And, it was suggested that the middle water column in each ecosystem is the most proper column for human usage.

\section{INTRODUCTION}

Creshwaters are one of the most important resources for humans and other living things in the world and they should be safe for human consumption. But, they can naturally contain bacteria and their bacterial content can change negatively as a result of discharges from domestic, industrial and agricultural activities. In recent years increasing population, industrial developments, and agricultural activities have led to pollution in freshwater ecosystems in both lentic (stagnant water) and lotic (running water) biotopes. Both physicochemical properties and qualitative/quantitative distributions of organisms have been used to 
determine the quality of inland waters. The determination of fecal indicator bacterial distributions is of great importance in the studies of aquatic ecosystems $(1,2,3,4)$, especially the contents of coliform bacteria and E. coli bacteria which are known as indicator microorganisms. Also, some environmental parameters can be affected as a result of their distributions $(5,6,7,8,9)$, as, physicochemical features can change vertically and horizontally in the water and the bacterial distribution can be affected by the changing environment.

In this study, indicator bacteria for fecal pollution were counted at different freshwater locations in Turkish Thrace. The vertical and horizontal distribution of fecal indicator bacteria in two different ecosystems (Meric River as running water resource and Kayalikoy reservoir as stagnant water resource) in Meric-Ergene River Basin at Turkish Thrace were investigated comparatively. For this reason, two sampling locations in each biotope were chosen. The Meric River is the most important tributary of Meric-Ergene River Basin and the main supply for agricultural irrigation for the rice fields in the Basin. The Kayalikoy dam lake reservoir plays an important role in the water supply for Edirne and Kirklareli Provinces for drinking, irrigation or other intentions in the Basin. Also, some statistical analyses were used to evaluate the relationships between the bacterial distribution and environmental parameters. The heavy metal content of water columns and sediments in sampling stations were also determined in this study.

Thus, the most advantageous water column of water resource for stagnant and running waters both lotic and lentic biotopes in the area were suggested.

\section{MATERIALS AND METHODS}

In this study, two different freshwater resources (Meric River and Kayalikoy dam lake reservoir) in Turkish Thrace were determined as sampling ecosystems for lotic and lentic systems. Water samples were taken from surface, middle and bottom water in the stations by using a Nansen water sampler and were put into $100 \mathrm{~mL}$ of sterile sampling bottles. Sediment samples were taken by the Ekman Grab from shore and bottom mud (the top $10 \mathrm{~mm}$ of the sediment used for bacterial counting) and were put into sterile plastic bags. Samples were kept in ice boxes in the dark and were transported to the laboratory within a few hours.

Heterotrophic bacteria (HB) counts were determined by the spread plate method (Plate Count Agar, $35^{\circ} \mathrm{C} \pm$ $0.5^{\circ} \mathrm{C}$ at 48 hours) (10). Total coliform (TCB), fecal coliform (FCB) and E. coli bacteria were determined by the using multiple-tube fermentation technique (through the presumptive-confirmed phases or completed test) (10). The MPN (Most Probable Number) technique was applied to determine bacterial counts by using standard tables for five tubes (10). The LST Broth $\left(35^{\circ} \mathrm{C} \pm 0.5^{\circ} \mathrm{C}\right.$ at $24 \pm 2$ hours $)$ and BGLBB Broth $\left(35^{\circ} \mathrm{C} \pm 0.5^{\circ} \mathrm{C}\right.$ at 24 \pm 2 hours) was used as media for total coliform bacteria and EC Broth $\left(44.5^{\circ} \mathrm{C} \pm 0.2^{\circ} \mathrm{C}\right.$ at $24 \pm 2$ hours) were used as indicator media and incubation conditions for fecal coliform bacteria (10). Also EC Broth with MUG $\left(44.5^{\circ} \mathrm{C} \pm 0.2{ }^{\circ} \mathrm{C}\right.$ at $24 \pm 2$ hours), TW Broth $\left(35.5^{\circ} \mathrm{C} \pm\right.$ $0.2^{\circ} \mathrm{C}$ at $24 \pm 2$ hours), and EMB Agar $\left(35.5^{\circ} \mathrm{C} \pm 0.2^{\circ} \mathrm{C}\right.$ at $18-24$ hours) were used as indicator culture media and incubation conditions for E.coli bacteria (10).

The temperature, $\mathrm{pH}$, dissolved oxygen (DO), conductivity (EC), and salinity were measured when the same time with bacterial sampling during the field studies. The water samples were taken by a Nansen water sampler and were transferred to the laboratory for the other parameters to be measured (calcium, magnesium, nutrients, chloride, and heavy metals). The analyses were made in TUTAGEM (Technology Researches and Development Applications and Research Center) laboratories.

\section{RESULTS AND DISCUSSION}

The heterotrophic bacteria counts were found to be higher than the other bacterial counts (total coliform (TCB), fecal coliform (FCB) and E. coli bacteria) at each biotope and each sampled water column. Furthermore, it was found that the bacterial content is higher in the lotic ecosystem than that the lentic ecosystem (Table 1). In the previous studies, it has been mentioned that fecal coliform bacteria were studied at the surface and bottom water (above the sediment), and the counts of bacteria at the surface were higher than that at the bottom $(1,11,12)$. Also, Koloren et al. (3) reported that the TCB has been found with the highest counts at surface and bottom water column, but FCB counts were found to be higher at the surface rather than that the bottom. Cardak and Altug (2) reported that the highest bacteria count in the bottom were caused by deep discharges to the water from domestic or agricultural activities. Furthermore, Pote et al. (4) discussed that the high bacterial accounts at the bottom were related to increased temperature, biological activity and predation by bacterivorous organisms, as well as UV radiation.

The numbers of $\mathrm{HB}$ were found in the highest concentration at the surface in all sampling seasons for both lentic and lotic ecosystems (Figure 1a-e). TCB numbers in lentic ecosystem were found at the highest concentrations at the surface in spring, winter, and summer seasons and in the bottom at autumn (Figure 2a). While FCB were determined at highest concentrations at the bottom in all sampling seasons in both lotic (except summer) and lentic ecosystems, E. coli bacteria were found at highest levels in all sampling seasons at the bottom except autumn (Table 1). Furthermore, it was observed that bacterial distribution has higher in shore sediments in the lotic ecosystem (Figure 1f and 2f). But, it was observed that 

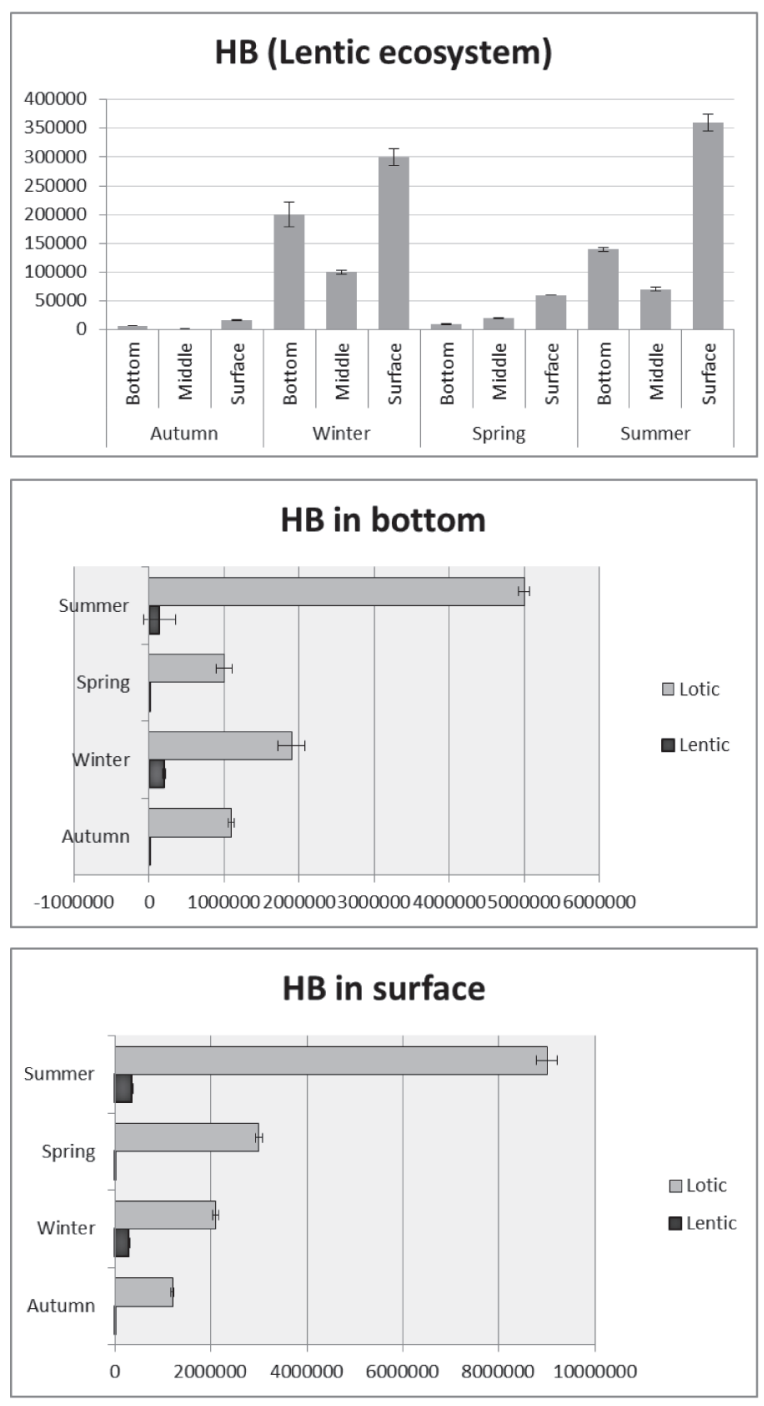
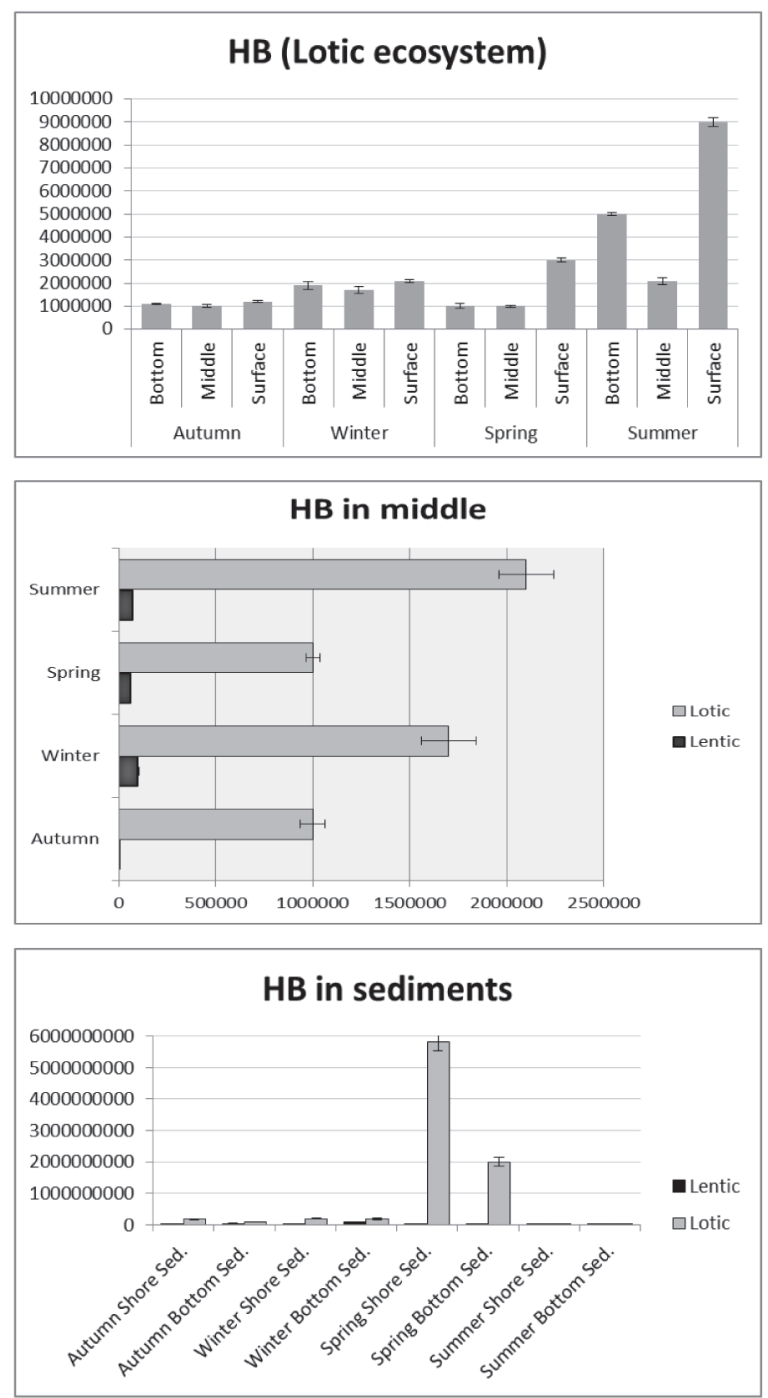

Figure 1. The vertical, horizontal and seasonal comparisons of heterotrophic bacteria (HB) counts in the lotic and lentic ecosystems: (a) HB in lentic ecosystem, (b) HB in lotic ecosystem, (c) HB in bottom, (d) HB in middle, (e) HB in surface, (f) HB in sediments

the bacterial counts have very high concentrations in bottom sediments at the lentic ecosystem (Figure 1f and 2f).

The inland waters are classified according to physicochemical properties by the Water Pollution Control Regulation (13). The highest quality water is classified as first quality level; the moderate quality water is classified as second quality level; and lowest quality water is classified as third and fourth quality levels. The quality classes include different amounts of TCB as MPN $100^{-1} \mathrm{~mL}(100$, 20000, 100000, >100000 respectively), and FCB as MPN $100^{-1} \mathrm{~mL}(10,200,2000$, >2000, respectively). While it was found that the bacterial load for HB in winter has the highest concentration in a lentic ecosystem (winter $>$ summer $>$ spring $>$ autumn in lentic ecosystem), the bacterial load for HB in summer was found at the highest level in a lotic ecosystem (summer > winter > spring > autumn in lotic ecosystem) (Figure 1a, b). But,
TCB concentrations in summer, spring, and winter for each ecosystem were found to be higher than the autumn season (Figure 2). While the HB counts in this study have not exceeded the first quality level in lentic biotope, the lotic biotope has exceeded the first quality level for the numbers of TCB. Furthermore, in some seasons, FCB numbers also exceeded second quality levels in lotic biotope, only. While the TCB and FCB numbers were found at first quality levels in lentic ecosystem, the numbers in lotic ecosystem corresponded to second quality levels (13). Furthermore, the numbers of FCB in lotic ecosystem have been found to exceed the second quality level. According to the vertical distribution of TCB, FCB and $E$. coli bacteria, it was found the lowest counts were the middle column at lotic ecosystem. Therefore, it is suggested to take the irrigation/tap water from at middle column of water resources. In the previous study performed in a stream water resource by Altinoluk et al. (14), 
Table 1. The seasonal, vertical, and horizontal distributions of bacteria in the lotic and lentic ecosystems (Units are cfu $100^{-1} \mathrm{~mL}$ for $H B$ and $M P N 100^{-1} \mathrm{~mL}$ for other bacteria in water columns; cfu $100^{-1} \mathrm{~g}$ for HB and MPN $100^{-1} \mathrm{~g}$ for other bacteria in sediments), (HB: heterotrophic bacteria, TCB: total coliform bacteria, FCB: faecal coliform bacteria, E.coli: Escherichia coli, cfu: colony forming unit, MPN: most probable number, \pm standard deviation)

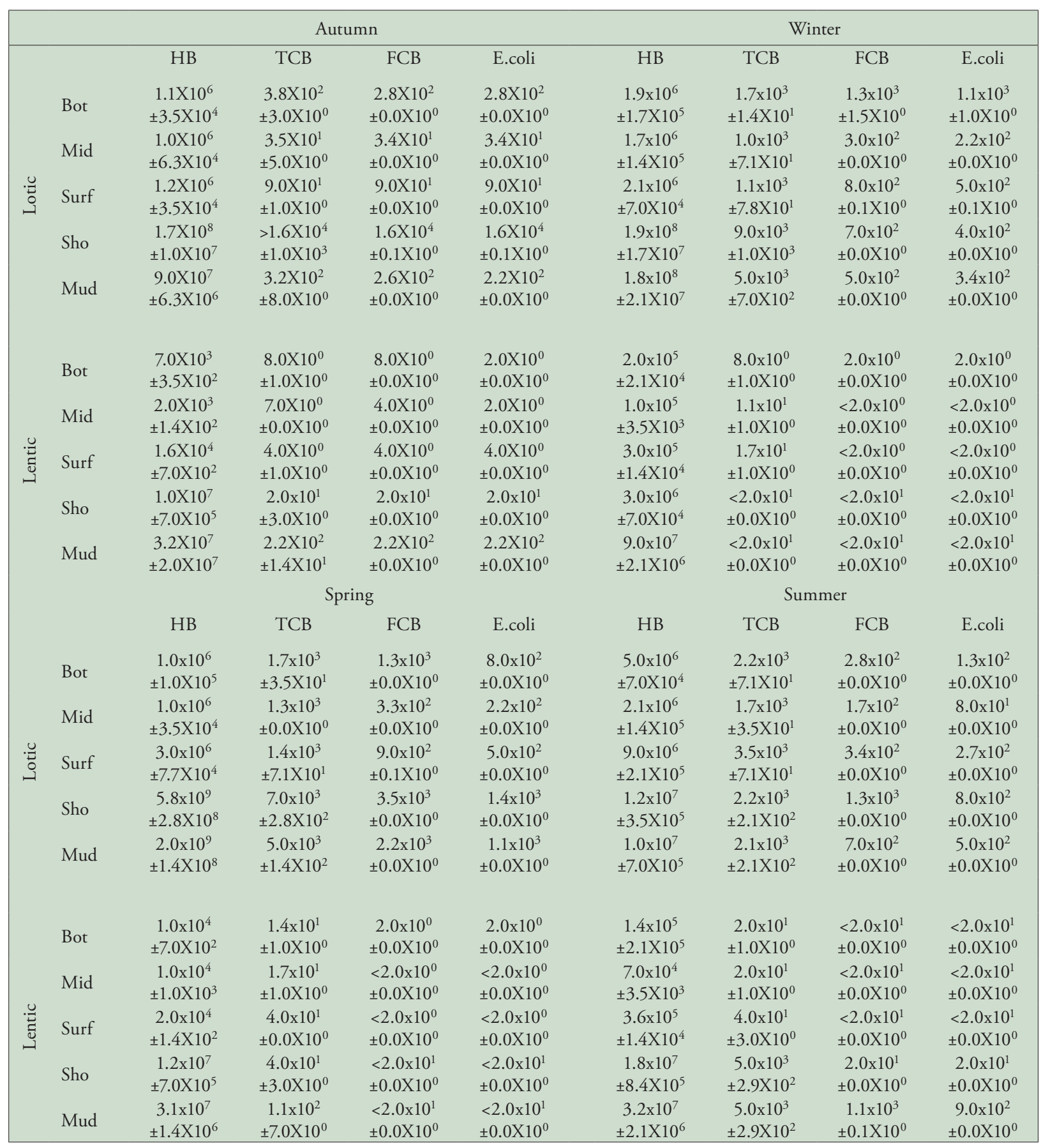

it was reported that bacterial groups were at the highest concentration in surface water, the lowest number of bacteria was recorded at the depth of middle. This increase can be explained by agricultural, domestic and industrial wastewaters discharged into the water. It was also suggested that the surface water should not be used for irrigation (14).
According to the Bray-Curtis similarity results, the bacterial distribution in each ecosystem was similar for both the bottom and surface water columns, except in the spring season (Figure 3a). The findings of Correspondence analyse results supported the Bray-Curtis results (Figure 3b). Also, the effects of physicochemical factors such as temperature, $\mathrm{DO}, \mathrm{pH}$ and suspended solids can 

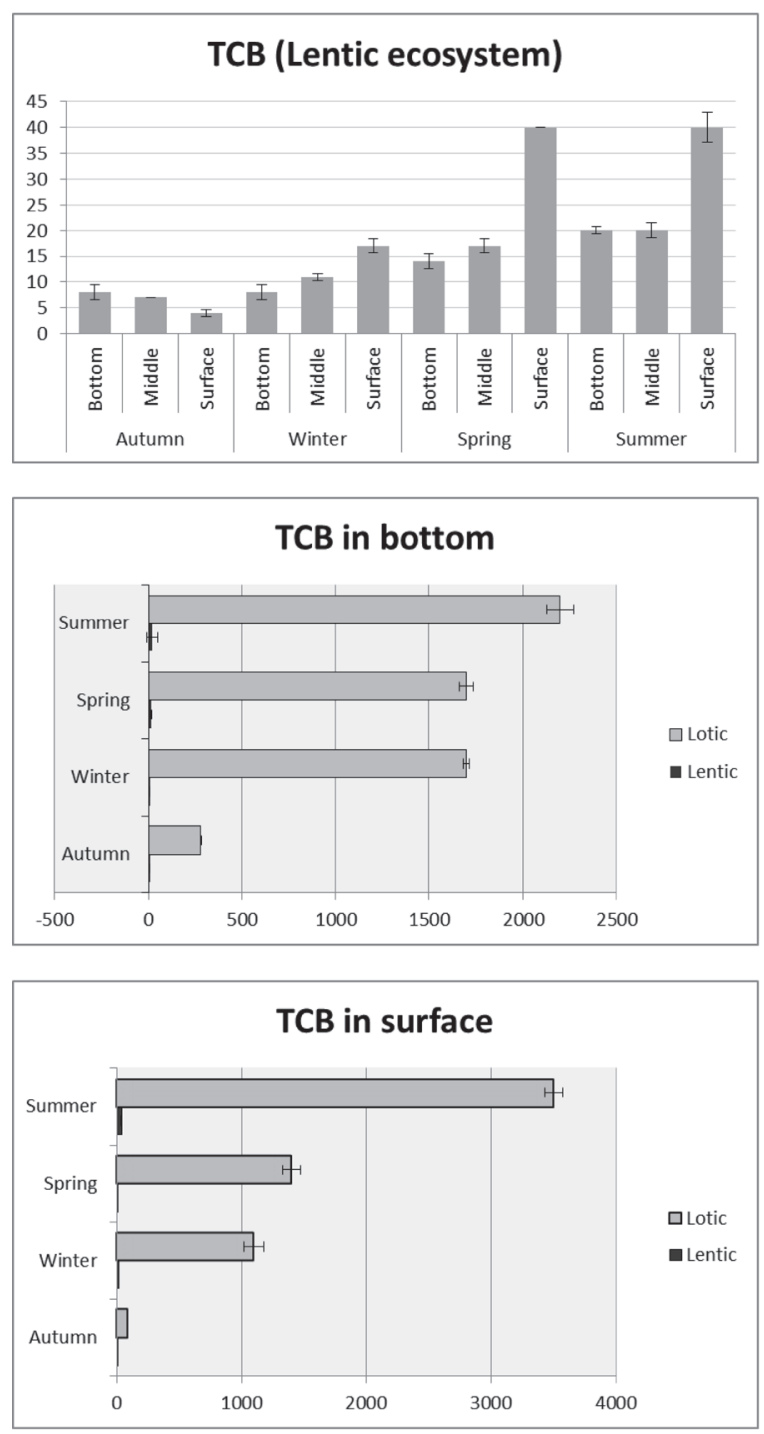
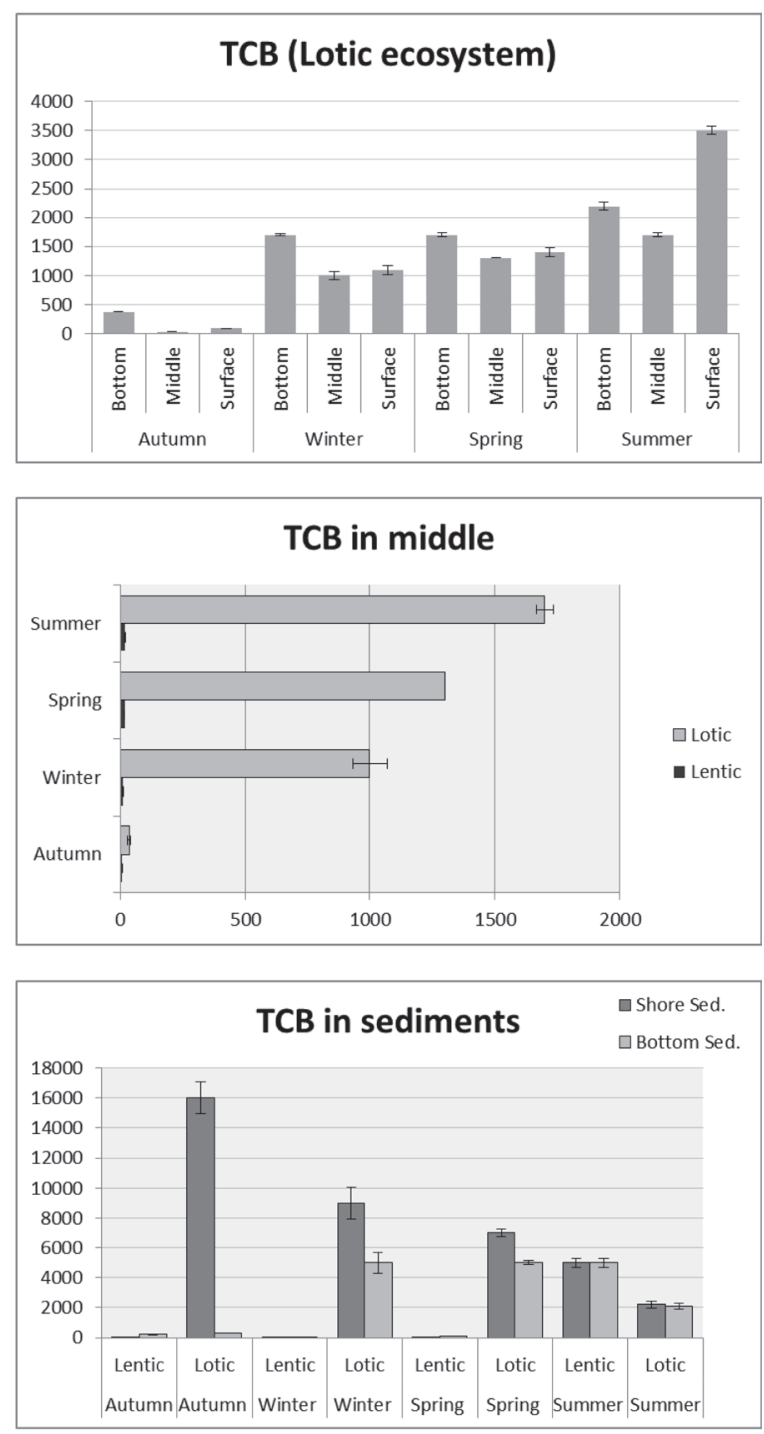

Figure 2. The vertical, horizontal and seasonal comparisons of total coliform bacteria (TCB) counts in the lotic and lentic ecosystems: (a) TCB in lentic ecosystem, (b) TCB in lotic ecosystem, (c) TCB in bottom, (d) TCB in middle, (e) TCB in surface, (f) TCB in sediments

affect the distribution of bacteria (15). In the present study, while the temperature values observed normal for the season, EC, salinity and chloride values were measured to have freshwater features in each ecosystem (Table 2). Also, an inverse proportion was observed between the $\mathrm{DO}$ values and temperature at each ecosystem. According to $\mathrm{pH}$ values, the lentic ecosystem was found to be third quality level because of values exceeding 9.0 in spring and summer seasons (Table 2). Although the Spearman correlation was used on the data, there were no remarkable relationships between these parameters and bacterial counts in this study ( $p>0.05)$.

Although some heavy metals are important elements for growth of plants, excessive concentrations of them have toxic effects for both plants and microorganisms, and these elements accumulate in soil. In aquatic ecosys- tems, sediment also accumulates a lot of pollutants like organic matter, phosphate, nitro-compounds, and heavy metals until saturated and then sediments release these compounds to the water bodies. As the $\mathrm{pH}$ of the water decreases, and increased amount of metal is released from sediment into the water and the redox potential of the water column increases. In this study, some heavy metal concentrations were also measured at each ecosystem in the different water columns and sediments (Table 3). According to the results, the values of sodium $(\mathrm{Na})$, chromium $(\mathrm{Cr})$, manganese $(\mathrm{Mn})$, ferro $(\mathrm{Fe})$, cobalt $(\mathrm{Co})$, nickel $(\mathrm{Ni})$, copper $(\mathrm{Cu})$, zinc $(\mathrm{Zn})$, arsenic $(\mathrm{As})$ and cadmium (Cd) of the water columns were measured at first quality level and aluminium $(\mathrm{Al})$, lead $(\mathrm{Pb})$, selenium $(\mathrm{Se})$ were measured at third quality level except summer seasons when they were measured at very low quality level at each ecosystem (Table 3). In sediment samples, including 


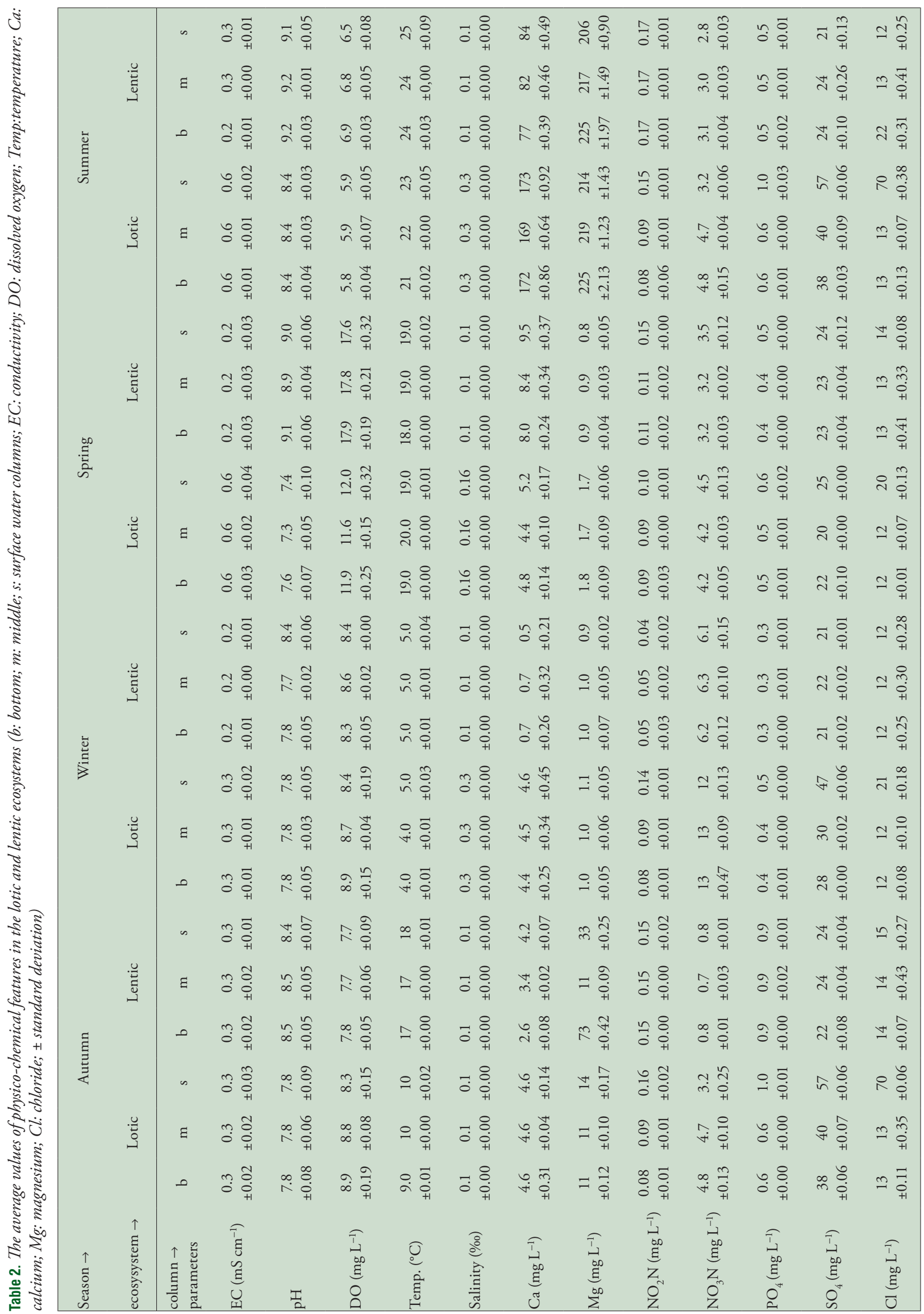




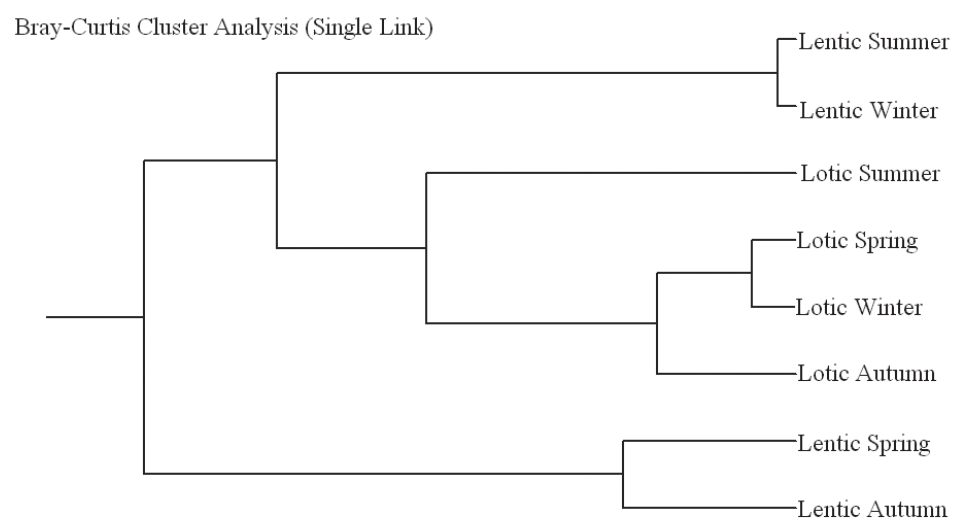

0, Similarity $\% \quad 50, \quad 100$

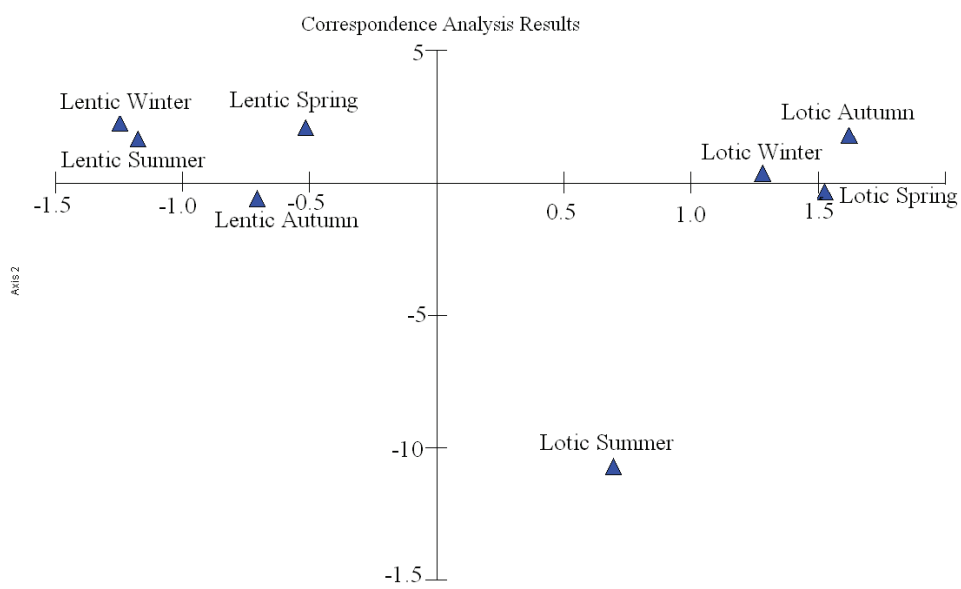

Figure 3. Statistical analyses result on vertical distributions of bacteria in the sampled lotic and lentic ecosystems: (a) Bray-Curtis cluster analysis, (b) Correspondence analysis

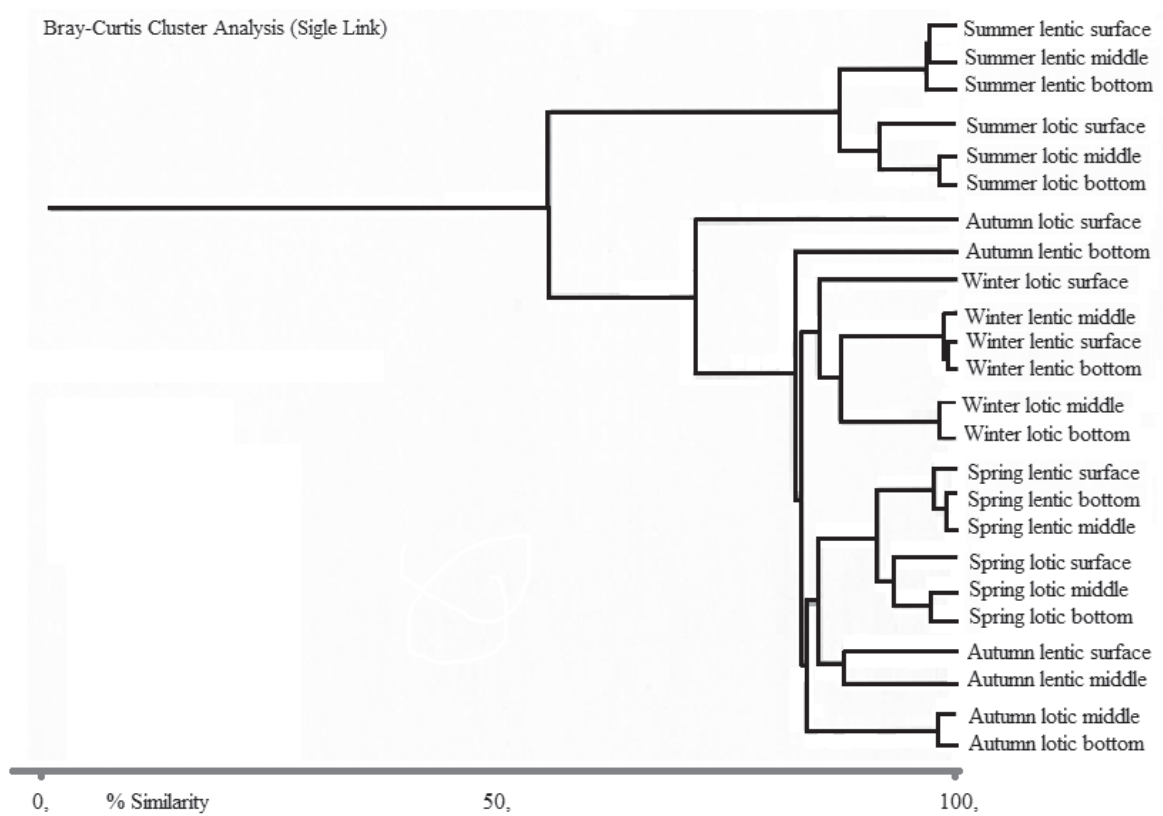

Figure 4. Bray-Curtis similarity index results for physicochemical analyses in lentic and lotic ecosystems 
Table 3. The heavy metal concentrations in the ecosystems (bot: bottom; mid: middle; surf: surface; sho: shore; mud: deep sediment)

\begin{tabular}{|c|c|c|c|c|c|c|c|c|c|c|c|c|c|c|c|}
\hline & & & $\mathrm{Na}$ & $\mathrm{Al}$ & $\mathrm{Cr}$ & $\mathrm{Mn}$ & $\mathrm{Fe}$ & Co & $\mathrm{Ni}$ & $\mathrm{Cu}$ & $\mathrm{Zn}$ & As & $\mathrm{Se}$ & $\mathrm{Cd}$ & $\mathrm{Pb}$ \\
\hline \multirow{10}{*}{ 胥 } & \multirow{6}{*}{. } & bot* & 0.02 & 0.00 & 0.01 & 0.05 & 1.759 & 0.00 & 0.04 & 0.04 & 0.09 & 0.00 & 0.02 & 0.00 & 0.05 \\
\hline & & $\operatorname{mid}^{*}$ & 0.02 & 0.04 & 0.01 & 0.07 & 3.500 & 0.00 & 0.06 & 0.04 & 0.1 & 0.00 & 0.02 & 0.00 & 0.05 \\
\hline & & surf* & 0.05 & 0.03 & 0.01 & 0.06 & 2.903 & 0.00 & 0.04 & 0.03 & 0.07 & 0.00 & 0.02 & 0.00 & 0.05 \\
\hline & & sho $^{* *}$ & 0.14 & 6.41 & 21.8 & 212 & 6547 & 2.97 & 27.2 & 11.2 & 77 & 4.26 & 0.73 & 0.93 & 24.8 \\
\hline & & $\operatorname{mud}^{* *}$ & 0.28 & 10.0 & 22.5 & 491 & 11638 & 5.10 & 14.4 & 20.1 & 153 & 12.1 & 1.37 & 0.24 & 65.2 \\
\hline & & bot* & 0.59 & 0.00 & 0.01 & 0.01 & 0.095 & 0.00 & 0.04 & 0.02 & 0.09 & 0.01 & 0.02 & 0.00 & 0.04 \\
\hline & \multirow{4}{*}{ } & $\operatorname{mid}^{*}$ & 0.02 & 0.00 & 0.01 & 0.02 & 0.095 & 0.00 & 0.03 & 0.02 & 0.09 & 0.00 & 0.02 & 0.00 & 0.04 \\
\hline & & surf* & 0.08 & 0.00 & 0.01 & 0.02 & 0.096 & 0.00 & 0.05 & 0.02 & 0.1 & 0.00 & 0.02 & 0.00 & 0.05 \\
\hline & & sho** & 0.03 & 4.37 & 2.75 & 81.4 & 5163 & 1.62 & 4.80 & 0.71 & 23 & 0.82 & 0.86 & 0.01 & 3.48 \\
\hline & & $\operatorname{mud}^{* *}$ & 0.04 & 5.56 & 4.67 & 116 & 6255 & 1.98 & 0.36 & 1.50 & 19 & 1.01 & 0.75 & 0.02 & 4.33 \\
\hline \multirow{10}{*}{ 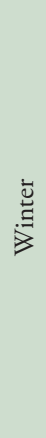 } & \multirow{6}{*}{ 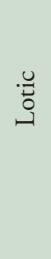 } & bot $^{*}$ & 0.02 & 0.00 & 0.01 & 0.02 & 0.26 & 0.00 & 0.05 & 0.02 & 0.09 & 0.00 & 0.01 & 0.00 & 0.05 \\
\hline & & $\operatorname{mid}^{*}$ & 0.02 & 0.00 & 0.01 & 0.02 & 0.26 & 0.00 & 0.05 & 0.02 & 0.09 & 0.00 & 0.01 & 0.00 & 0.05 \\
\hline & & surf* & 0.02 & 0.00 & 0.01 & 0.02 & 0.24 & 0.00 & 0.05 & 0.02 & 0.09 & 0.00 & 0.01 & 0.00 & 0.05 \\
\hline & & sho** & 0.06 & 1.05 & 2.25 & 291 & 1638 & 0.51 & 2.34 & 2.31 & 83.1 & 0.45 & 0.67 & 0.24 & 4.21 \\
\hline & & mud $^{* *}$ & 0.07 & 1.03 & 2.51 & 280 & 1508 & 0.69 & 2.33 & 2.38 & 83.9 & 0.48 & 0.69 & 0.29 & 4.83 \\
\hline & & bot* & 0.00 & 0.00 & 0.01 & 0.01 & 0.38 & 0.00 & 0.01 & 0.03 & 0.12 & 0.00 & 0.01 & 0.00 & 0.06 \\
\hline & \multirow{4}{*}{ } & mid* $^{*}$ & 0.00 & 0.00 & 0.01 & 0.01 & 0.38 & 0.00 & 0.01 & 0.03 & 0.11 & 0.00 & 0.01 & 0.00 & 0.06 \\
\hline & & surf* & 0.00 & 0.00 & 0.01 & 0.01 & 0.40 & 0.00 & 0.01 & 0.03 & 0.11 & 0.00 & 0.01 & 0.00 & 0.06 \\
\hline & & sho $^{* *}$ & 0.04 & 0.09 & 0.97 & 2.82 & 40.4 & 0.55 & 2.82 & 3.40 & 11.4 & 0.45 & 1.95 & 0.60 & 6.54 \\
\hline & & $\operatorname{mud}^{* *}$ & 0.04 & 0.09 & 0.97 & 2.82 & 40.4 & 0.55 & 2.82 & 3.40 & 11.4 & 0.45 & 1.95 & 0.60 & 6.54 \\
\hline \multirow{10}{*}{$\begin{array}{l}\stackrel{\infty}{\Xi} \\
\text { के }\end{array}$} & \multirow{5}{*}{ 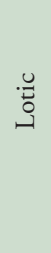 } & bot* & 0.00 & 0.00 & 0.01 & 0.01 & 2.14 & 0.00 & 0.02 & 0.04 & 0.06 & 0.00 & 0.51 & 0.00 & 0.06 \\
\hline & & mid* $^{*}$ & 0.00 & 0.00 & 0.01 & 0.01 & 2.09 & 0.00 & 0.02 & 0.05 & 0.07 & 0.00 & 0.49 & 0.00 & 0.09 \\
\hline & & surf* & 0.00 & 0.00 & 0.01 & 0.00 & 2.08 & 0.00 & 0.02 & 0.04 & 0.07 & 0.00 & 0.49 & 0.00 & 0.05 \\
\hline & & sho** & 0.19 & 11.3 & 21.8 & 427 & 8206 & 4.55 & 10.8 & 28.9 & 95.9 & 5.71 & 1.34 & 1.34 & 34.9 \\
\hline & & $\operatorname{mud}^{* *}$ & 0.18 & 12.1 & 25.5 & 307 & 9078 & 4.10 & 10.1 & 25.4 & 100 & 5.65 & 1.45 & 1.45 & 33.0 \\
\hline & \multirow{5}{*}{ } & bot* & 0.00 & 0.00 & 0.01 & 0.02 & 1.28 & 0.00 & 0.01 & 0.03 & 0.05 & 0.00 & 0.12 & 0.00 & 0.05 \\
\hline & & $\mathrm{mid}^{*}$ & 0.00 & 0.00 & 0.01 & 0.02 & 1.27 & 0.00 & 0.01 & 0.03 & 0.07 & 0.00 & 0.11 & 0.00 & 0.05 \\
\hline & & Surf* & 0.00 & 0.00 & 0.01 & 0.02 & 1.20 & 0.01 & 0.02 & 0.08 & 0.06 & 0.00 & 0.04 & 0.00 & 0.05 \\
\hline & & sho $^{* *}$ & 0.02 & 0.34 & 0.38 & 6.03 & 333 & 0.11 & 1.92 & 0.56 & 4.69 & 5.23 & 0.04 & 0.04 & 0.85 \\
\hline & & $\operatorname{mud}^{* *}$ & 0.02 & 0.25 & 0.33 & 4.15 & 199 & 0.17 & 0.61 & 0.46 & 1.43 & 5.69 & 0.01 & 0.04 & 0.75 \\
\hline \multirow{10}{*}{ 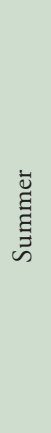 } & \multirow{5}{*}{ لِّ } & bot $^{*}$ & 0.44 & 0.00 & 0.26 & 1.52 & 18.4 & 0.02 & 0.27 & 0.45 & 1.25 & 0.08 & 2.30 & 0.00 & 0.10 \\
\hline & & mid* $^{*}$ & 0.42 & 0.00 & 0.24 & 0.80 & 16.9 & 0.02 & 0.25 & 0.49 & 0.75 & 0.07 & 2.10 & 0.00 & 0.05 \\
\hline & & surf* & 0.47 & 0.00 & 0.24 & 0.81 & 15.7 & 0.02 & 0.17 & 0.12 & 0.31 & 0.08 & 1.93 & 0.00 & 0.06 \\
\hline & & sho $^{* *}$ & 0.10 & 3.03 & 5.17 & 122 & 164 & 1.72 & 4.31 & 3.05 & 31.4 & 1.61 & 1.29 & 0.01 & 8.23 \\
\hline & & $\operatorname{mud}^{* *}$ & 0.28 & 16.3 & 37.4 & 279 & 260 & 6.93 & 15.9 & 117 & 254 & 33.3 & 4.08 & 0.12 & 149 \\
\hline & \multirow{5}{*}{ 号 } & bot $^{*}$ & 0.25 & 0.00 & 0.34 & 0.53 & 31.0 & 0.02 & 1.02 & 0.43 & 0.38 & 0.04 & 3.22 & 0.00 & 0.03 \\
\hline & & mid $^{*}$ & 0.33 & 0.00 & 0.35 & 0.59 & 30.2 & 0.02 & 0.54 & 0.37 & 0.39 & 0.05 & 3.11 & 0.00 & 0.04 \\
\hline & & surf* & 0.23 & 0.00 & 0.36 & 0.60 & 28.9 & 0.04 & 1.83 & 0.10 & 0.27 & 0.08 & 3.02 & 0.02 & 0.16 \\
\hline & & sho** & 0.05 & 0.27 & 2.99 & 73.3 & 271 & 1.78 & 1.98 & 1.39 & 11.2 & 0.62 & 2.66 & 0.00 & 1.94 \\
\hline & & $\operatorname{mud}^{* *}$ & 0.07 & 0.47 & 6.83 & 130 & 177 & 2.51 & 3.60 & 2.48 & 22.0 & 1.07 & 3.49 & 0.00 & 3.02 \\
\hline
\end{tabular}

${ }^{*} \mathrm{mg} \mathrm{mL}^{-1} ;{ }^{* *} \mathrm{mg} \mathrm{g}^{-1}$

of lead $(\mathrm{Pb})$, chromium $(\mathrm{Cr})$, and copper $(\mathrm{Cu})$ were measured lower in the lentic than the lotic and it was found at higher values in the bottom sediment than the shore at almost all sediments except winter (equal). According to the heavy metal measurements, it was suggested to take water for irrigation or other intentions from near the shore and middle water column in the water supply.

Each bacterial species has its own specific survival rate and unique response characteristics that determine their distribution over depth and time (1). Therefore, all fresh- 
water ecosystems should be monitored periodically for bacterial distribution and environmental conditions to provide safe water resources for human consumption.

\section{CONCLUSIONS}

Consequently, the study has supported the theory that the bacterial distribution can differ in both water columns/sediment depths and lotic and lentic ecosystems. According to the results from this study, it is suggested that water should be taken from middle column and near the shore of water supply. However, all aquatic ecosystems are different from each other likewise humans and therefore, it is suggested that both bacterial distribution and physicochemical properties of water columns should be examined for a water supply before being used for irrigation or other purposes (to determine the most advantageous water column or location to take the water from a water resource).

Acknowledgements: This study has been produced from first author's PhD thesis which was supported by the Trakya University Research Fund with Project Number TUBAP$2014 / 54$.

\section{REFERENCES}

1. Bergstein-Ben Dan T, Stone L 1991 The distribution of fecal pollution indicator bacteria in Lake Kinneret. Water Research 25(3): 263-270. https://doi.org/10.1016/0043-1354(91)90005-B

2. Cardak M, Altug G 2010 Distribution of members of the family Enterobacteriaceae in the Istanbul Strait. Journal of Black Sea/ Mediterranean Environment 16(3): 295-310.

3. Koloren Z, Tas B, Kaya D 2011 Microbiological pollution of Gaga Lake in Ordu (Turkey). The Black Sea Journal of Sciences 1(3): 74-85.

4. Pote J, Goldscheider N, Haller L, Zopf J, Khajehnouri F, Wildi W 2009 Origin and spatial-temporal distribution of faecal bacteria in a Bay of Lake Geneva, Switzerland. Environmental Monitoring and
Assessment 154(1-4): 337-348.

https://doi.org/10.1007/s10661-008-0401-8

5. Niewolak S, Golas I 2000 Estimation of the degree of pollution and sanitary and bacteriological state of underground and surface waters in Omulewski aquifer area after liquidation of large cattle and pig farms. Polish Journal of Environmental Studies 9(6): 487-503.

6. Anderson KL, Whitlock JE, Harwood WJ 2005 Persistence and differential survival of fecal indicator bacteria in subtropical waters and sediments. Applied Environmental Microbiology 71(6): 30413048. https://doi.org/10.1128/AEM.71.6.3041-3048.2005

7. Agbogu VN, Umoh VJ, Okuofu CA, Smith SI, Ameh JB 2006 Study of the bacteriological and physico-chemical indicators of pollution of surface waters in Zaria, Nigeria. African Journal of Biotechnology 5(9): 732-737.

8. Servais P, Billen G, Goncalves A, Armisen T 2007 Modelling microbiological water quality in the Seine River drainage network past, present and future situations. Hydrology and Earth System Sciences 11: 1581-1592. https://doi.org/10.5194/hess-11-1581-2007

9. Mishra A, Bhatt VD, Sevak N, Shah P, Patel K, Patel C 2010 Comparative study of physico-chemical and microbial parameters on lotic and ground-waters in selected outlying areas of central Gujarat. Journal of Chemistry and Pharmacological Researches 2(4): 174-177.

10. APHA 1998 Standard Methods for the Examination of Water and Wastewater, 20th Edition. American Public Health Association, Washington, D.C.

11. Ribeiro CH, Kjerfve B 2002 Anthropogenic influence on the water quality in Guanabara Bay, Rio de Janeiro, Brazil. Regional Environmental Change 3(1-3): 13-19.

https://doi.org/10.1007/s10113-001-0037-5

12. Mesteres M, Sierra JP, Pascual, Mösso C, Gonzalez del Rio J, Rodilla M 2009 Bacterial pollution in Cullera Bay (Spanish Mediterranean Coast). Journal of Coastal Research 56: 861-865.

13. SKKY 2004 Su Kirliligi Kontrol Yonetmeligi (Water Pollution Control Administration), Official Gazette No: 25687 of 13 December 2004, Ankara, Turkey.

14. Altinoluk P, Camur-Elipek B, Aydogdu H 2014 Vertical dynamics of some indicator microorganisms in Tunca River at Turkish Thrace. Macedonian Journal of Ecology and Environment 16: 5-9.

15. Elmaci A, Teksoy A, Topac FO, Ozengin N, Baskaya HS 2008 Monitoring of seasonal variation of microbial quality in Lake Ulubat. Uludag University Journal of The Faculty of Engineering and Architecture 13(1): 93-103. 